\title{
Impact of Human Capital Inequality on Total Factor Productivity in China
}

\author{
Chongyi Gong \\ School of Economics, Jinan University, Guangzhou, China \\ Email: 619142118@qq.com
}

Received 22 April 2016; accepted 13 May 2016; published 16 May 2016

Copyright (C) 2016 by author and Scientific Research Publishing Inc.

This work is licensed under the Creative Commons Attribution International License (CC BY). http://creativecommons.org/licenses/by/4.0/

c) (i) Open Access

\begin{abstract}
This paper investigates the impact of human capital inequality on Total Factor Productivity (TFP) in China. Approaching this question in dynamic panel data over 18 years and 29 provinces with first-order difference GMM and system GMM estimators reveals: human capital inequality has a significant negative effect on TFP, and high-quality human capital has a significant positive effect on TFP.
\end{abstract}

\section{Keywords}

\section{Total Factor Productivity, Human Capital Inequality, Human Capital Gini Coefficient}

\section{Introduction}

Since 1978, China's economy has maintained a rapid growth of more than 30 years. The total economic output ranks second in the world. But it should be noted that China's economic growth is mainly dependent on factor inputs of capital, energy, resources and labors, and the contribution of total factor productivity is small. At this stage, China's economic problem has become increasingly apparent, such as the excessive consumption of resources, environmental deterioration, and low industrial structure. All these seriously restrict the sustainable development of the economy of China. So improving China's TFP is helpful for transferring China's economic growth model from extensive to intensive and it is helpful for China to maintain the long-term economic growth.

The impact of human capital on TFP is one of the highlights in economic research. Since Schultz [1], the research on the impact of human capital on economic growth is too much. Phelps and Nelson [2] point out that human capital can help workforce to create, learn and use more new technologies, and thus promote the TFP. But the empirical research has failed to reach a consensus conclusion. On the one hand, a part of the studies support a positive relationship between human capital and TFP, as Benhabib and Spiegel [3] point out that human capital can promote technology progress and technology diffusion, which can promote TFP. On the other 
hand, the other part of the research finds that there is no positive relationship between human capital and TFP, such as Pritchett [4] shows that there is a significant negative relationship between TFP and human capital.

The problem is that the existing literatures take the human capital as a whole to study the impact of human capital on TFP, without considering human capital inequality's impact on TFP. For the studies of human capital inequality, a large number of studies concentrate on the impact of human capital inequality on economic growth, and other studies concentrate on the relationships of human capital inequality and average human capital, income inequality, expected life, and investment rate. There are rare studies concentrating on the impact of human capital inequality on TFP. Considering that human capital has important effect on TFP, human capital inequality is likely to have effect on TFP. How does human capital inequality affect TFP is the main problem of this paper.

The innovations of this paper are as follows: First, using first-order difference GMM and System GMM estimation to analysis the data of 29 provinces in China from 1996 to 2013, finding that human capital inequality has a significant negative effect on TFP. Second, from the theoretical and empirical analysis, this paper finds that the mechanism of human capital affect TFP is that "high-quality human capital has a positive effect on TFP by affecting technology innovation, and human capital inequality has a negative effect on TFP by affecting technology diffusion".

The significance of this paper has two aspects: First, the theoretical significance of this paper is: it can rich the existing literatures of the impact of human capital on TFP. In the existing literatures, the impact of human capital on TFP is mainly focused on the impact of the average human capital on TFP, ignoring the effect of human capital inequality. Therefore, the study of the impact of human capital inequality on TFP can enrich the theory of the impact of human capital on TFP. Second, the practical significance of this paper is: it can help the growth of TFP and economy. Especially in China, which is now in the critical period of transformation of economic growth mode, a correct understanding of the impact of human capital inequality on TFP, can be better to develop human capital policies to promote TFP growth, in order to realize the sustainable growth of China's economy.

This paper is structured as follows: the first part is the introduction; the second part is the models, variables and data; the third part is the empirical analysis results; the fourth part is the conclusion.

\section{Models, Variables and Data}

\subsection{Models}

Human capital inequality has negative effect on TFP because it can affect technology diffusion. First, Acemoglu [5] points out that the advanced technologies of developed countries are matched with developed countries' labors. Because labors' human capital in developed countries is bigger than in developing countries, developed countries' advanced technologies are not matched with developing countries' labors. Thus even if the developing countries can introduce advanced technology from developed countries, due to the matching problem; developing countries cannot quickly master the advanced technology. Developing countries' TFP cannot rapidly grow. Second, the individual communication can spread ideas, and thus promote TFP. The communication between the individual can be affected by social differences, because people communicate more with those who are similar to themselves. A person's friends tend to have similar education, income, age, hometown with this person. As an aspect of social differences, human capital inequality influences the individual communication. Therefore, if the human capital inequality is big, the communications among individuals will less, thus hinders the spread of ideas and the growth of TFP.

The bigger human capital inequality, the slower technology diffusion speed, the slower technological progress, the slower TFP growth rate, thus results the first equation of the relationship between human capital inequality and TFP:

$$
\ln \mathrm{TFP}_{\mathrm{it}}-\ln \mathrm{TFP}_{\mathrm{it}-1}=\mathrm{f}\left(\mathrm{G}_{\mathrm{it}-1}\right)
$$

where ln means taking the logarithm, i denotes provinces, t denotes the year, $G$ denotes human capital Gini coefficient. On the left is the TFP's logarithmic difference, which means TFP growth rate.

Because human capital inequality only represent the distribution differences of human capital, but does not represent the level of human capital, so it needs another variable to represent the level of human capital. This paper uses the high-quality human capital to represent the level of human capital for two reasons. First, Vandenbussche [6], Manca [7] find high quality human capital, but not average human capital, has positive effect on 
TFP. These researches show that high quality human capital promotes TFP by affecting technology innovation and introduction. Second, Castllo and Domenech (2002) [8] find human capital inequality and average human capital is linear, which will lead these two variables cannot all be significantly in regression. So this paper uses high-quality human capital represent the level of human capital, and there is the second equation of human capital inequality and TFP:

$$
\ln \mathrm{TFP}_{\mathrm{it}}-\ln \mathrm{TFP}_{\mathrm{it}-1}=\mathrm{f}\left(\mathrm{G}_{\mathrm{it}-1}, \text { High }_{\mathrm{it}-1}\right)
$$

where High denotes high quality human capital.

Human capital inequality has a negative effect on TFP by affecting technology diffusion, and high-quality human capital has a positive effect on TFP by affecting technology innovation and introduction. So this paper points out the mechanism of human capital affect TFP is that "high-quality human capital has a positive effect on TFP by affecting technology innovation, and human capital inequality has a negative effect on TFP by affecting technology diffusion”.

\subsection{Human Capital Inequality}

Human capital inequality is measured by human capital Gini coefficient. According to Vinod [9], the formula of human capital Gini coefficient is:

$$
\mathrm{G}=\frac{1}{\mathrm{H}} \sum_{\mathrm{i}=2}^{\mathrm{n}} \sum_{\mathrm{j}=1}^{\mathrm{i}-1}\left|\mathrm{E}_{\mathrm{i}}-\mathrm{E}_{\mathrm{j}}\right| \mathrm{P}_{\mathrm{i}} \mathrm{P}_{\mathrm{j}}
$$

where $G$ is human capital inequality; $E_{i}$ and $E_{j}$ is the years of education, this paper set illiteracy $E_{1}=0$, primary $E_{2}=6$, junior $E_{3}=9$, high $E_{4}=12$, tertiary $E_{5}=16 ; P_{i}$ and $P_{j}$ is the ratios of each level education person on total person; $H$ is the average education years, $H=E_{1} P_{1}+E_{2} P_{2}+E_{3} P_{3}+E_{4} P_{4}+E_{5} P_{5}$.

\subsection{Total Factor Productivity}

Because there are defects to calculate TFP based on Solow model. So according to Hall and Jones [10], this paper calculates TFP based on the modified Solow model. It is assumed that the total production function are Cobb-Douglas form, $\mathrm{Y}=\mathrm{K}^{\alpha}(\mathrm{ALH})^{1-\alpha}$, where $\mathrm{Y}$ denotes the total output, $\mathrm{K}$ denotes the physical capital, $\mathrm{L}$ denotes labors and $\mathrm{H}$ denotes the average human capital of labors, A denotes TFP.

$$
\text { Definite } \mathrm{y}=\frac{\mathrm{Y}}{\mathrm{L}} \text {, translate } \mathrm{Y}=\mathrm{K}^{\alpha}(\mathrm{ALH})^{1-\alpha} \text { to } \mathrm{y}=\mathrm{A}\left(\frac{\mathrm{K}}{\mathrm{Y}}\right)^{\frac{\alpha}{1-\alpha}} \mathrm{H} \text {, then } \ln \mathrm{A}=\ln \mathrm{y}-\frac{\alpha}{1-\alpha} \ln \frac{\mathrm{K}}{\mathrm{Y}}-\ln \mathrm{H} \text {. Ac- }
$$

cording to the existing research, this paper sets $\alpha=0.4$.

\subsection{Data}

This paper uses a panel data for 29 provinces in China over the period 1996-2013, not including Tibet, for its data is not available, also not including Hong Kong, Macao and Taiwan for the political and economic systems of these regions are different from Chinese Mainland. The education constitutes data using to calculate human capital Gini coefficient is from the China Labor Statistics Yearbook.

The GDP data using to calculate TFP are from the China Statistical Yearbook. The labor force data are from the China Statistical Yearbook. The real capital stock data are calculated by the perpetual inventory method.

\section{Results}

By equation (1) and (2), the model can be obtained:

$$
\begin{gathered}
\ln \mathrm{TFP}_{\mathrm{it}}-\ln \mathrm{TFP}_{\mathrm{it}-1}=\alpha_{1}+\beta_{1} \ln \mathrm{G}_{\mathrm{it}-1}+\gamma \mathrm{X}+\varepsilon_{\text {lit }} \\
\ln \mathrm{TFP}_{\mathrm{it}}-\ln \mathrm{TFP}_{\mathrm{it}-1}=\alpha_{2}+\beta_{2} \ln \mathrm{G}_{\mathrm{it}-1}+\lambda_{2} \ln \mathrm{High}_{\mathrm{it}-1}+\gamma \mathrm{X}+\varepsilon_{2 \mathrm{it}}
\end{gathered}
$$

where ln means logarithm, i denotes provinces, t denotes the year, $\mathrm{G}$ denotes the human capital Gini coefficient, High is high quality human capital. X denotes control variables, concluding industry, market and open. Due to the endogenous problem, use static panel estimation model (4) and (5) can’t guarantee estimation results' accuracy. So, transfer model (4) and (5) to (6) and (7): 


$$
\begin{gathered}
\ln \mathrm{TFP}_{\mathrm{it}}=\ln \mathrm{TFP}_{\mathrm{it}-1}+\alpha_{1}+\beta_{1} \ln \mathrm{G}_{\mathrm{it}-1}+\gamma \mathrm{X}+\varepsilon_{\mathrm{lit}} \\
\ln \mathrm{TFP}_{\mathrm{it}}=\ln \mathrm{TFP}_{\mathrm{it}-1}+\alpha_{2}+\beta_{2} \ln \mathrm{G}_{\mathrm{it}-1}+\lambda_{2} \ln \mathrm{High}_{\mathrm{it}-1}+\gamma \mathrm{X}+\varepsilon_{2 \mathrm{it}}
\end{gathered}
$$

Model (6) and (7) are dynamic models containing dependent variable’s first order lag variable. In order to enhance the robustness of the results, this paper estimates the model (6) and (7) using the dynamic panel first order difference GMM and the system GMM estimation method, the results are shown in Table 1.

The (1) and (2) columns in Table 1 are the estimation results of the model (6), the last two columns are the estimation results of model (7). Each equation is estimated using the first order difference GMM method and the system GMM method. Abond test shows that the disturbance term is not self related, which means it's proper to use the first order difference GMM and the system GMM method. Sargan test means the instrumental variables are effective. The (1) and (2) columns in Table 1 show that the human capital inequality and TFP has a significant negative correlation. Specifically, the coefficients of human capital inequality are -0.351 and -0.185 , and these are significant in the $1 \%$ significant level. This shows that the human capital inequality has a negative effect on TFP; it's consistent with the previous theoretical analysis.

The last two columns of Table 1 shows that the human capital inequality has a negative effect on TFP, and the high quality human capital has a significant positive effect on TFP. Specific, both the first-order difference GMM and System GMM estimation results show that high-quality human capital's coefficients are positive and significant at the $1 \%$ significant level, indicating that the high-quality human capital can promote TFP. This is consistent to Vandenbussche [6], Manca [7]. Human capital inequality's coefficient is negative and it's significant in at least $10 \%$ significant level. This shows that the high-quality human capital promote TFP and human capital inequality inhibit TFP, supporting the mechanism-high-quality human capital has a positive effect on TFP by affecting technology innovation, and human capital inequality has a negative effect on TFP by affecting

\begin{tabular}{|c|c|c|c|c|}
\hline \multirow{2}{*}{ Variables } & \multicolumn{4}{|c|}{$\operatorname{lnTFP}_{t}$} \\
\hline & (1) & (2) & (3) & (4) \\
\hline $\operatorname{lnTFP} P_{t-1}$ & $\begin{array}{l}0.843^{* * *} \\
(60.67)\end{array}$ & $\begin{array}{l}0.912^{* * *} \\
(54.37)\end{array}$ & $\begin{array}{l}0.821^{* * *} \\
(44.03)\end{array}$ & $\begin{array}{l}0.893^{* * *} \\
(40.11)\end{array}$ \\
\hline $\ln G_{t-1}$ & $\begin{array}{c}-0.351^{* * *} \\
(-11.86)\end{array}$ & $\begin{array}{c}-0.185^{* * *} \\
(-4.51)\end{array}$ & $\begin{array}{c}-0.132^{* * *} \\
(-2.93)\end{array}$ & $\begin{array}{l}-0.094^{*} \\
(-1.90)\end{array}$ \\
\hline $\operatorname{lnHigh}_{t-1}$ & & & $\begin{array}{c}0.086^{* * *} \\
(5.79)\end{array}$ & $\begin{array}{c}0.058^{* * *} \\
(4.14)\end{array}$ \\
\hline Indus $_{t-1}$ & $\begin{array}{l}0.210 \\
(1.21)\end{array}$ & $\begin{array}{l}-0.004 \\
(-0.02)\end{array}$ & $\begin{array}{l}-0.031 \\
(-0.19)\end{array}$ & $\begin{array}{c}-0.597^{* * *} \\
(-3.38)\end{array}$ \\
\hline market $_{\mathrm{t}-1}$ & $\begin{array}{l}0.128 \\
(1.28)\end{array}$ & $\begin{array}{l}0.052 \\
(0.84)\end{array}$ & $\begin{array}{l}0.060 \\
(0.70)\end{array}$ & $\begin{array}{l}-0.054 \\
(-0.88)\end{array}$ \\
\hline open $_{t-1}$ & $\begin{array}{l}0.032 \\
(0.99)\end{array}$ & $\begin{array}{l}0.005 \\
(0.15)\end{array}$ & $\begin{array}{l}0.032 \\
(1.29)\end{array}$ & $\begin{array}{l}0.006 \\
(0.20)\end{array}$ \\
\hline _cons & $\begin{array}{c}-0.929^{* * *} \\
(-11.20)\end{array}$ & $\begin{array}{c}-0.477^{* * *} \\
(-4.44)\end{array}$ & $\begin{array}{c}-0.807^{* * *} \\
(-7.43)\end{array}$ & $\begin{array}{c}-0.491^{* * *} \\
(-3.54)\end{array}$ \\
\hline $\mathrm{AR}(1)$ & 0.0012 & 0.0023 & 0.0058 & 0.0042 \\
\hline $\mathrm{AR}(2)$ & 0.6523 & 0.4852 & 0.6512 & 0.3575 \\
\hline Sargan test & 1.000 & 1.000 & 1.000 & 1.000 \\
\hline $\mathrm{N}$ & 464 & 493 & 464 & 493 \\
\hline
\end{tabular}
technology diffusion.

Note: ${ }^{*} \mathrm{p}<0.10 ;{ }^{* *} \mathrm{p}<0.05 ;{ }^{* * *} \mathrm{p}<0.01$. T statistics are in brackets. AR(1), AR(2) and Sargan test are $\mathrm{p}$ value. (1) and (3) is the first-order difference GMM regression results; (2) and (4) is the system GMM regression results. 
This shows that if a province has a lot of high-quality human capital, but human capital inequality level is very high, the TFP growth rate of this province may not quickly. If a province has not a lot of high-quality human capital, but the human capital inequality level is very low, the TFP growth rate of this province may quickly. This is in line with China's Hunan Province and Hubei Province, as shown in Table 2. From 1996 to 2013, the annual average high-quality human capital of Hunan Province is only $4.6 \%$, is lower than Hubei Province's $5.58 \%$, but the annual average TFP growth rate of Hunan Province is $6.48 \%$, which is greater than Hubei Province's 4.89\%. Considering that the annual average human capital Gini coefficient of Hunan Province is only 0.194, smaller than Hubei Province's 0.229, this kind of phenomenon is common.

Phelps and Nelson [2] points out that the human capital cannot simply be regarded as a factor of production to analyze its impact on economic growth, but also should pay attention to the impact of human capital on TFP. The empirical results support the above mentioned effect on the human capital of the TFP mechanism, high-quality human capital through the technology innovation and the introduction of a positive effect on TFP, and human capital inequality by affecting technology diffusion inhibitory effect on TFP. In this way, a country or region which is in the effort to improve the TFP, should not only focus on the improvement of high quality human capital, but also should pay attention to ease the problem of human capital inequality.

\section{Conclusions and Policy Recommendations}

\subsection{Conclusions}

This paper uses dynamic panel first-order difference GMM and System GMM estimation method to test a panel data of 29 provinces over the period 1996-2013 in China. The empirical results show that human capital inequality has significant negative effect on TFP; high-quality human capital has a significant positive effect on TFP. So when analyzing the relationship of human capital and TFP, it should not only need to consider the effect of the high quality human capital, but also need to consider the effect of human capital inequality. From the theoretical and empirical analysis, this paper finds that the mechanism of human capital affect TFP is that "highquality human capital has a positive effect on TFP by affecting technology innovation, and human capital inequality has a negative effect on TFP by affecting technology diffusion". This indicates that if a region wants to promote TFP, it should not only pay attention to improve the quality of human capital, but also should pay attention to reduce the human capital inequality. Taking Hunan Province and Hubei Province in China as an example, although Hubei Province's high-quality human capital is more, but due to the relatively high human capital inequality, so the TFP growth rate is not high. Hunan province's high-quality human capital is not much, but because the human capital inequality level is low, so the TFP growth rate is relatively high.

\subsection{Policy Recommendations}

Thus the corresponding policy recommendations are: when attracting high-quality human capital, it should also pay attention to human capital inequality. Because simply raise the high-quality human capital but does not take into account human capital inequality, may not good to TFP. Specific recommendations are as follows:

\subsection{Pay More Attention to the Effect of Human Capital on TFP}

For a long time, China's economic growth mainly depends on the capital, energy, resources and labors, and the contribution of TFP is not high. This "extensive" mode of economic growth needs to consume a lot of resources and damage the environment, which is not a sustainable way. Therefore, transferring China's economic growth from the extensive development mode into the intensive mode has become an important task of China's current

Table 2. Hunan and Hubei's high quality human capital, TFP growth rate and human capital inequality.

\begin{tabular}{ccc}
\hline Variables & Hunan province & Hubei province \\
\hline High quality human capital & $4.60 \%$ & $5.58 \%$ \\
TFP growth rate & $6.48 \%$ & $4.89 \%$ \\
Human capital inequality & 0.194 & 0.229 \\
\hline
\end{tabular}


economic development. Human capital has an important influence on TFP, so improving China's TFP is helpful for transferring China's economic growth model from extensive to intensive and it is helpful for China to maintain the long-term economic growth. China should improve the investment of human capital. Considering the human capital' externality and public welfare, national finance must be the main source of human capital investment. Therefore, in order to improve China's human capital, China's government should strengthen the investment of human capital.

\subsection{Pay More Attention to Human Capital Inequality, Timely Implement Compulsory Education for 12 Years}

While improving human capital, it's should also pay attention to human capital inequality. This paper shows that human capital inequality will inhibit TFP. So improve the TFP, should not only focus on the improvement of human capital, but also should pay more attention to the problem of human capital inequality. First, China should pay attention to the reduction of regional education difference. Although China has basically achieved 9 years of compulsory education, the differences in the human capital of China's provinces are reduced, but the regional differences are still very large. Therefore, China should pay more attention to the western and middle regions. Second, China should promote the 12 year compulsory education. Education expansion is an important way to reduce the inequality of human capital, so after 9 years of compulsory education, China should promote the 12 years compulsory education.

\subsection{Pay More Attention to the Introduction of High-Quality Human Capital, and Further Develop High Education}

High-quality human capital plays a significant role in promoting TFP, and has an important effect on the long-term economic growth. Taking into account the high-quality human capital is the inventor and the introductory of new technology. China should continue to implement the strategy of talent introduction. At the same time, China should further develop high education and train more high-quality labor force. While developing of “quantity of high education”, China should also pay more attention to improving the "quality of high education”.

\section{References}

[1] Schultz, T.W. (1960) Capital Formation by Education. Journal of Political Economy, 68, 571-583. http://dx.doi.org/10.1086/258393

[2] Nelson, R. and Phelps, E. (1966) Investment in Humans, Technological Diffusion, and Economic Growth. The American Economic Review, 56, 69-75.

[3] Benhabib, J. and Spiegel, M. (1994) The Role of Human Capital in Economic Development: Evidence from Aggregate Cross-Country Data. Journal of Monetary Economics, 34, 143-173. http://dx.doi.org/10.1016/0304-3932(94)90047-7

[4] Pritchett, L. (2001) Where Has All the Education Gone. World Bank Economic Review, 15, 367-391. http://dx.doi.org/10.1093/wber/15.3.367

[5] Acemoglu, D. and Zilibotti, F. (2001) Productivity Differences. Quarterly Journal of Economics, 116, 563-606. http://dx.doi.org/10.1162/00335530151144104

[6] Vandenbussche, J., Aghion, P. and Meghir, C. (2006) Growth, Distance to Frontier and Composition of Human Capital. Journal of Economic Growth, 11, 97-127. http://dx.doi.org/10.1007/s10887-006-9002-y

[7] Manca, F. (2012) Human Capital Composition and Economic Growth at the Regional Level. Regional Studies, 46, 1367-1388. http://dx.doi.org/10.1080/00343404.2011.598503

[8] Castello, A. and Domenech, R. (2002) Human Capital Inequality and Economic Growth: Some New Evidence. The Economic Journal, 112, 187-200. http://dx.doi.org/10.1111/1468-0297.00024

[9] Vinod, T., Wang, Y. and Fan, X.B. (2001) Measuring Education Inequality: Gini Coefficients of Education. World Bank Working Paper, 25-125.

[10] Hall, R.E. and Jones, C.I. (1999) Why Do Some Countries Produce So Much More Output per Worker than Others. Quarterly Journal of Economics, 114, 83-116. http://dx.doi.org/10.1162/003355399555954 